\title{
Ferruginibacter alkalilentus gen. nov., sp. nov. and Ferruginibacter lapsinanis sp. nov., novel members of the family 'Chitinophagaceae' in the phylum Bacteroidetes, isolated from freshwater sediment
}

Correspondence

Sung-Taik Lee

e_stlee@kaist.ac.kr

\author{
Ju Hyoung Lim, Sang-Hoon Baek and Sung-Taik Lee
}

\author{
Environmental and Molecular Microbiology Lab., Department of Biological Sciences, KAIST, 335 \\ Gwahangno, Yuseong-gu, Daejeon 305-701, Republic of Korea
}

The phylum Bacteroidetes (Garrity \& Holt, 2001) is phenotypically diverse and still undergoing considerable taxonomic revision. Several members formerly misclassified in the genera Flexibacter and Cytophaga have been transferred to the genus Chitinophaga (Kämpfer et al., 2006), which originally belonged to the family Crenotrichaceae (Approved Lists 1980) that should not be used any more as its type genus, Crenothrix, turned out to belong to the phylum Proteobacteria (Stoecker et al., 2006) [Rule 37a (1)]. A new family, 'Chitinophagaceae', was subsequently suggested to be created for the genus Chitinophaga on the basis of 16S rRNA gene phylogenetic analyses (Ludwig et al., 2008), which also indicated that the genera Terrimonas (Xie \& Yokota, 2006), Niastella (Weon et al., 2006), Niabella (Kim et al., 2007), Flavisolibacter (Yoon \& Im, 2007) and others are phylogenetically classified in the same family. Sediment from a freshwater lake was investigated for bacterial culturability and diversity by $\operatorname{Lim}$ et al. (2008), and six novel isolates, HU1-GD23 ${ }^{\mathrm{T}}$, HU1-GB11, HU1-ID41, HU1-IH3, HU1-

The GenBank/EMBL/DDBJ accession numbers for the newly determined 16S rRNA gene sequences of strains HU1-GD23 ${ }^{\top}$, HU1-IH3, HU1-HG42', HU1-JE21, HU1-ID41 and HU1-GB11 are FJ177530-177532 and FJ263932-263934, respectively.
JE21 and HU1-HG42 ${ }^{\mathrm{T}}$ were found to be phylogenetically related to members of the family 'Chitinophagaceae'. On the basis of further taxonomic studies, we propose here that strain HU1-GD23 ${ }^{\mathrm{T}}$ along with four other strains and HU1-HG42 ${ }^{\mathrm{T}}$ represent two novel species of a novel genus, Ferruginibacter gen. nov. within the family 'Chitinophagaceae' of the phylum Bacteroidetes.

Sediment samples were collected from a littoral zone of Lake Hakha $\left(36^{\circ} 17^{\prime} \mathrm{N}, 127^{\circ} 18^{\prime} 32^{\prime \prime} \mathrm{E}\right)$, a typical freshwater lake in South Korea, and subjected to dilution-toextinction cultivation (Button et al., 1993) in 96-well plates, wherein cells were enriched on unsupplemented lake water media of low nutritional status for 3 months, followed by the detection of extinction wells, as described previously by $\mathrm{Lim}$ et al. (2008). Single colonies were isolated on 1:10-diluted R2A agar (Difco) plates to which bacterial suspension had been transferred from the wells containing pure cultures. The isolates were then routinely propagated aerobically on $\mathrm{R} 2 \mathrm{~A}$ agar at $30{ }^{\circ} \mathrm{C}$ for 5 days.

Colonies were directly applied to $16 \mathrm{~S}$ rRNA gene PCR and amplified fragments were then sequenced using the primers 27F and 1100R (Lane, 1991), 341F and 534R (Muyzer et al., 1993) and 907F (Lane et al., 1985). Sequences were assembled with SEQMAN II 5.0 (DNASTAR) (Swindell \& 
Plasterer, 1997) and compared with all 16S rRNA gene sequences available in the GenBank database. Alignment of sequences was carried out with CLUSTAL_X (Thompson et al., 1997). Gaps at the $5^{\prime}$ and $3^{\prime}$ ends and ambiguous bases were removed from the alignment using BIOEDIT (Hall, 1999). Phylogenetic trees based on comparison of 1283 bases were constructed by the neighbour-joining (Saitou \& Nei, 1987) and the maximum-parsimony (Fitch, 1971) algorithms using MEGA version 3.1 (Kumar et al., 2004). Evolutionary distances were calculated using Kimura's two-parameter model (Kimura, 1983) and bootstrap values were based on 1000 replications (Felsenstein, 1985). Chromosomal DNA was extracted and purified using Qiagen Genomic-tip system 100/G for determination of $\mathrm{G}+\mathrm{C}$ content, which was measured as described by Mesbah et al. (1989) using reverse-phase HPLC (Younglin).

Cell morphology and motility were examined by phasecontrast microscopy. Catalase and oxidase activities were determined by using standard methods (Cowan \& Steel, 1965). Gram test was performed according to Buck (1982). Presence of flexirubin-like pigment was investigated by flooding culture plates with $20 \%$ (w/v) KOH (Fautz \& Reichenbach, 1980). Substrate assimilation was tested on a defined liquid medium consisting of basal salts $\left(1^{-1}: 1.8 \mathrm{~g}\right.$ $\mathrm{K}_{2} \mathrm{HPO}_{4}, 1.08 \mathrm{~g} \mathrm{KH}_{2} \mathrm{PO}_{4}, 0.5 \mathrm{~g} \mathrm{NaNO}_{3}, 0.5 \mathrm{~g} \mathrm{NH}_{4} \mathrm{Cl}, 0.1 \mathrm{~g}$ $\mathrm{KCl}, 0.1 \mathrm{~g} \mathrm{MgSO}_{4}, 0.05 \mathrm{~g} \mathrm{CaCl}_{2}$ ), vitamin mixture (Widdel \& Bak, 1992), trace element solution SL-10 (Pedersen \& Ekendahl, 1990) and selenite/tungstate solution (Tschech \& Pfennig, 1984). The $\mathrm{pH}$ was adjusted to 6.8 and the medium was then supplemented with a single carbon source that had been filter-sterilized. Additional substrateutilization and biochemical characters were determined using API 32GN, API 20NE, API 20E and API ZYM galleries, according to the manufacturer's protocol
(bioMérieux). Results of API tests except for API ZYM were read after 10 days incubation. DNase activity was detected on DNase test agar (Scharlau) by flooding culture plates with $1 \mathrm{M} \mathrm{HCl}$. Hydrolysis of starch, chitin, aesculin and skim milk were examined according to Atlas (2004). Degradation of cellulose and xylan were also studied (Ten et al., 2004). Anaerobic growth was tested on R2A medium containing $1 \mathrm{~g}$ thioglycolate $\mathrm{l}^{-1}$ in a serum bottle with the headspace substituted by nitrogen gas. Nitrate reduction was carried out both aerobically and anaerobically in a serum bottle supplemented with $10 \mathrm{mM} \mathrm{KNO}_{3}$ as an electron acceptor, and was monitored by an ion chromatograph (Metrohm) equipped with a conductivity detector and anion exchange column. Isoprenoid quinones were determined as described by Komagata \& Suzuki (1987) using Sep-Pak Vac silica cartridges (Waters). For quantitative analysis of cellular fatty acid compositions, cells were harvested after 3 days incubation at $28{ }^{\circ} \mathrm{C}$ on $\mathrm{R} 2 \mathrm{~A}$, based on the culture conditions used for some members of the family 'Chitinophagaceae' that cannot grow on TSA (Weon et al., 2006; Qu \& Yuan, 2008). Cellular fatty acid methyl esters were prepared and identified following the protocol of the Sherlock Microbial Identification System (MIDI). All the phenotypic tests described above were performed more than twice with 5 days incubation, unless otherwise specified.

As shown in Fig. 1, the six new isolates were phylogenetically located within a cluster consisting of members of the genus Terrimonas and other recently validated genera in the family 'Chitinophagaceae'. This Terrimonas cluster has been displayed as a separate branch from the highly robust cluster comprising only members of the genus Chitinophaga (Kämpfer et al., 2006; Kim et al., 2007; Yoon \& Im, 2007; Ludwig et al., 2008). Comparison of $16 \mathrm{~S}$ rRNA gene sequences showed that strains HU1-GD23 ${ }^{\mathrm{T}}$ and

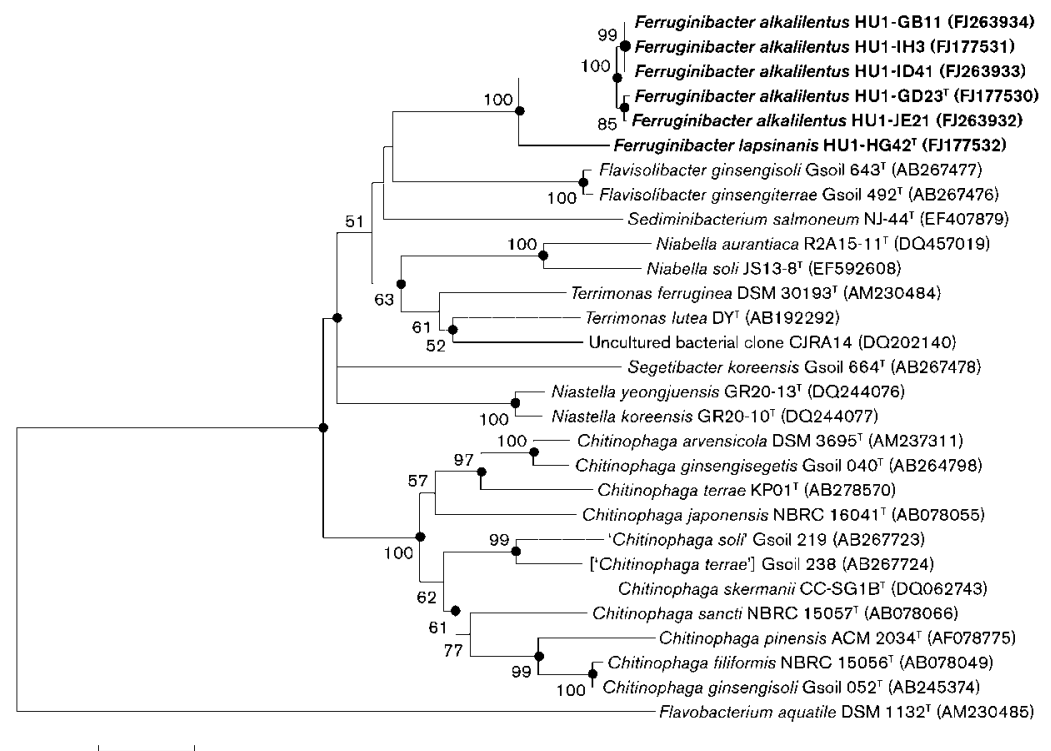

Fig. 1. Neighbour-joining bootstrap consensus tree, showing relationships between the six new isolates and phylogenetic members of the family 'Chitinophagaceae'. Bootstrap values of $50 \%$ or more (using 1000 replications) are indicated at branch points. Filled circles represent that the corresponding nodes were also recovered in maximum-parsimony trees. Accession numbers are shown in parentheses. Bar, 0.02 substitutions per nucleotide position. 
HU1-HG42 ${ }^{\mathrm{T}}$ had a sequence similarity of $96.2 \%$, forming a coherent cluster that shared considerably lower similarities with members of the genera Terrimonas (93.490.5\%), Flavisolibacter (92.1-91.6\%) and Niastella (91-90.6\%). Strain HU1-GD23 ${ }^{\mathrm{T}}$ and four more isolates that were tightly clustered together showed more than $99.6 \%$ similarity to each other, indicating they belong to the same genomic species (Fig. 1). DNA G $+\mathrm{C}$ contents of strain HU1-GD23 ${ }^{\mathrm{T}}$ and $\mathrm{HU} 1-\mathrm{HG} 42^{\mathrm{T}}$ were 39.4 and $38.5 \mathrm{~mol} \%$, respectively, close to those of previously identified members of 'Chitinophagaceae' (40.4$49.8 \mathrm{~mol} \%$ ). Strain HU1-GD23 ${ }^{\mathrm{T}}$ and the other four strains showed a very narrow range of $\mathrm{G}+\mathrm{C}$ content (39.4-39.5 mol\%), supporting their phylogenetic affiliation in the same genomic species.

All the isolates were Gram-negative, strictly aerobic, nonsporulating and optimally grew at $30{ }^{\circ} \mathrm{C}$ and $\mathrm{pH} 7$ in the absence of $\mathrm{NaCl}$. None of the strains showed filamentous morphology, gliding motility, chitinase activity or a flexirubin-positive reaction that have been shown to be differential characteristics for members of the genera Chitinophaga, Flexibacter and Cytophaga (Reichenbach, 1989a, b; Skerman, 1989). Lack of these traits is generally shared by non-Chitinophaga members of the family 'Chitinophagaceae' (Table 1). All the strains produced MK-7 as the major menaquinone. High levels of two isobranched fatty acids (iso- $\mathrm{C}_{15: 0}$ and iso- $\mathrm{C}_{17: 0} 3-\mathrm{OH}$ ) were in good agreement with the cellular fatty acid profiles of previously described members of the family 'Chitinophagaceae'. All the strains lacked cis-5-hexadecenoic acid $\left(\mathrm{C}_{16: 1} \omega 5 c\right)$ but possessed iso-pentadecenoic acid (iso- $\mathrm{C}_{15: 1} \mathrm{G}$ ) abundantly, a character typically found in non-Chitinophaga species (Weon et al., 2006, 2008; Xie \& Yokota, 2006; An et al., 2007; Kim et al., 2007; Yoon \& Im, 2007; Qu \& Yuan, 2008). Strain HU1-GD23 ${ }^{\mathrm{T}}$ along with the four other isolates and HU1-HG42 ${ }^{\mathrm{T}}$ were distinguished from each other by quantitative and some minor qualitative differences found in the fatty acid composition; the difference in the amount of summed feature 3 (iso-

Table 1. Phenotypic characteristics of the Ferruginibacter gen. nov. and related genera phylogenetically belonging to the family 'Chitinophagaceae'

Genera: 1, Ferruginibacter gen. nov.; 2, Terrimonas (data from Xie \& Yokota, 2006); 3, Flavisolibacter (Yoon \& Im, 2007); 4, Niastella (Weon et al., 2006); 5, Sediminibacterium (Qu \& Yuan, 2008); 6, Niabella (Kim et al., 2007; Weon et al., 2008); 7, Segetibacter (An et al., 2007); 8, Chitinophaga (Sangkhobol \& Skerman, 1981; Reichenbach, 1989a; Fujita et al., 1996; Kämpfer et al., 2006). All organisms are aerobic and Gram-negative. +, All species positive; -, all species negative; $\mathrm{W}$, all species weakly positive; $\mathrm{v}$, variable among species; ND, no data available.

\begin{tabular}{|c|c|c|c|c|c|c|c|c|}
\hline Characteristic & 1 & 2 & 3 & 4 & 5 & 6 & 7 & 8 \\
\hline Filamentous cell shape & - & - & - & + & - & - & - & $\mathrm{v}$ \\
\hline Cell length $(\mu \mathrm{m})$ & $1-5$ & $1-3$ & $0.6-6$ & $10-50$ & $1-1.2$ & $0.8-1.5$ & $1.6-2$ & $0.6-80$ \\
\hline Gliding motility & - & - & - & + & + & - & - & V \\
\hline Flexirubin reaction & - & - & - & - & - & + & $\mathrm{ND}$ & $+^{*}$ \\
\hline Growth at $37^{\circ} \mathrm{C}$ & - & + & $\mathrm{v}$ & $\mathrm{V}$ & + & - & - & $\mathrm{V}$ \\
\hline Growth on TSA & - & + & - & - & - & $+^{*}$ & - & $+^{*}$ \\
\hline Acid produced from glucose & - & + & - & - & + & - & - & $+^{*}$ \\
\hline Nitrate reduction & - & + & - & - & - & - & - & $\mathrm{V}$ \\
\hline Catalase/oxidase activity & $+/+$ & $\mathrm{w} /+$ & $\mathrm{v} / \mathrm{v}$ & $-/ \mathrm{v}$ & $+1+$ & $+/ \mathrm{V}$ & $+1+$ & $\mathrm{v} / \mathrm{v}$ \\
\hline \multicolumn{9}{|l|}{ Hydrolysis of: } \\
\hline L-Arginine & + & - & - & - & - & - & + & $\mathrm{V}$ \\
\hline Chitin & - & - & - & + & - & - & - & $\mathrm{V}$ \\
\hline Gelatin & + & + & + & + & ND & - & - & $\mathrm{v}$ \\
\hline 2-Naphthylcaprylate & - & + & + & - & ND & + & - & $\mathrm{V}$ \\
\hline $\begin{array}{l}\text { 2-Naphthylphosphate } \\
\text { (pH 5.4) }\end{array}$ & - & + & + & + & ND & + & + & $+^{*}$ \\
\hline Starch & - & $\mathrm{V}$ & - & - & ND & - & - & $\mathrm{V}$ \\
\hline Urea & + & - & - & - & - & - & + & $\mathrm{V}$ \\
\hline Quinone system & MK-7 & MK-7 & MK-7 & MK-7 & $\mathrm{ND}$ & MK-7 & MK-7 & MK-7 \\
\hline DNA G $+C$ content $(\mathrm{mol} \%)$ & $38.5-39.5$ & $47.2-48.9$ & $42.7-43$ & $44.3-45.8$ & 40.6 & 45 & 40.4 & $40.7-49.8$ \\
\hline Major fatty acids $\dagger$ & $\begin{array}{l}\text { iso- } \mathrm{C}_{15: 0}, \\
\text { iso- } \mathrm{C}_{17: 0} \\
3-\mathrm{OH} \text {, iso- } \\
\mathrm{C}_{15: 1} \mathrm{G}\end{array}$ & $\begin{array}{l}\text { iso- } \mathrm{C}_{15: 0}, \\
\text { iso- } \mathrm{C}_{17: 0} \\
3-\mathrm{OH} \text {, iso- } \\
\mathrm{C}_{15: 1} \mathrm{G}\end{array}$ & $\begin{array}{l}\text { iso- } \mathrm{C}_{15: 0}, \\
\text { iso- } \mathrm{C}_{17: 0} \\
3-\mathrm{OH}, \text { (iso- } \\
\mathrm{C}_{15: 1} \mathrm{G} \text { ) }\end{array}$ & $\begin{array}{l}\text { iso- } \mathrm{C}_{15: 0} \text {, } \\
\text { iso- } \mathrm{C}_{17: 0} \\
3-\mathrm{OH} \text {, iso- } \\
\mathrm{C}_{15: 1} \mathrm{G}\end{array}$ & $\begin{array}{l}\text { iso- } \mathrm{C}_{15: 0} \text {, } \\
\text { (iso- } \mathrm{C}_{17: 0} \\
\text { 3-OH), iso- } \\
\mathrm{C}_{15: 1} \mathrm{G}\end{array}$ & $\begin{array}{l}\text { iso- } \mathrm{C}_{15: 0}, \\
\text { iso- } \mathrm{C}_{17: 0} \\
3-\mathrm{OH} \text {, iso- } \\
\mathrm{C}_{15: 1} \mathrm{G}\end{array}$ & $\begin{array}{c}\text { iso- } \mathrm{C}_{15: 0} \\
\text { iso- } \mathrm{C}_{17: 0} \\
3-\mathrm{OH}, \\
\text { iso- } \mathrm{C}_{15: 1} \mathrm{G}, \\
\mathrm{C}_{16: 1} \omega 5 \mathrm{c}\end{array}$ & $\begin{array}{l}\text { iso- } \mathrm{C}_{15: 0}, \\
\text { (iso- } \mathrm{C}_{17: 0} \\
3-\mathrm{OH} \text { ), } \\
\mathrm{C}_{16: 1} \omega 5 c\end{array}$ \\
\hline
\end{tabular}

${ }^{\star}$ Data not available for some species.

$\dagger$ Components that exist in relatively small amounts $(<10 \%,>5 \%)$ are indicated in parentheses. 
$\mathrm{C}_{15: 0} 2-\mathrm{OH}$ and/or $\left.\mathrm{C}_{16: 1} \omega 7 c\right)$ was particularly noticeable (Table 2). Differences in the physiological and biochemical characteristics listed in Table 3 also supported their affiliation to two separate species. Strain HU1-GD $23^{\mathrm{T}}$ and the other four isolates shared major phenotypic and biochemical traits with some variations as listed in Tables 2 and 3, and the species description, clearly demonstrating they belonged to a single species.

All of the above genotypic, phenotypic and chemotaxonomic data indicate a high degree of probability that strains HU1-GD23 ${ }^{\mathrm{T}}$ and HU1-HG42 ${ }^{\mathrm{T}}$ are members of a new lineage within the Terrimonas cluster (Fig. 1). Therefore, it is appropriate to classify strains HU1-GD23 ${ }^{\mathrm{T}}$ and HU1$\mathrm{HG}_{4}{ }^{\mathrm{T}}$ as separate species of a novel genus in the family 'Chitinophagaceae', for which the name Ferruginibacter gen. nov. is proposed, with the names Ferruginibacter alkalilentus sp. nov. and Ferruginibacter lapsinanis sp. nov. for strains HU1-GD23 ${ }^{\mathrm{T}}$ and HU1-HG42 ${ }^{\mathrm{T}}$, respectively.

\section{Description of Ferruginibacter gen. nov.}

Ferruginibacter (Fer.ru.gi.ni.bac'ter. L. n. ferrugo, -inis colour of iron rust; N.L. masc. n. bacter a rod; N.L. masc. n. Ferruginibacter rust-coloured rod)

Table 2. Cellular fatty acid composition (\%) of Ferruginibacter species and Terrimonas ferruginea

Strains: 1, Ferruginibacter alkalilentus (5 strains included); 2, Ferruginibacter lapsinanis $\mathrm{HU} 1-\mathrm{HG}_{4}{ }^{\mathrm{T}}$; 3, Terrimonas ferruginea KCTC $2909^{\mathrm{T}}$. All the strains were subjected to the analysis after 3 days incubation at $28{ }^{\circ} \mathrm{C}$ on $\mathrm{R} 2 \mathrm{~A}$. Values for F. alkalilentus are represented as mean values $( \pm \mathrm{SD})$ for five strains with type-strain values indicated in parentheses. Summed feature $3=$ iso- $\mathrm{C}_{15: 0} 2-\mathrm{OH}$ and/or $\mathrm{C}_{16: 1} \omega 7 c$. ECL, Unknown fatty acid of equivalent chain-length with indicated number of carbons.

\begin{tabular}{|c|c|c|c|}
\hline Fatty acid & 1 & 2 & 3 \\
\hline ECL 11.543 & $1.2 \pm 0.4(1.5)$ & - & - \\
\hline iso- $\mathrm{C}_{13: 0}$ & $0.3 \pm 0.4(0.6)$ & 3.2 & 0.9 \\
\hline ECL 13.565 & $1.6 \pm 0.5(2.1)$ & 1.1 & 0.7 \\
\hline iso- $\mathrm{C}_{14: 0}$ & $0.2 \pm 0.4$ & - & - \\
\hline $\mathrm{C}_{14: 0}$ & $0.7 \pm 0.5$ & - & 0.8 \\
\hline iso- $\mathrm{C}_{15: 1} \mathrm{G}$ & $21.7 \pm 1.2(22.3)$ & 21.7 & 26.1 \\
\hline anteiso- $\mathrm{C}_{15: 1} \mathrm{~A}$ & - & - & 1.2 \\
\hline iso- $\mathrm{C}_{15: 0}$ & $30.2 \pm 1.9(30.4)$ & 32.1 & 27.3 \\
\hline anteiso- $\mathrm{C}_{15: 0}$ & $1.6 \pm 0.4(2.0)$ & - & 2.4 \\
\hline $\mathrm{C}_{15: 0}$ & $1.6 \pm 0.5(2.1)$ & - & 4.1 \\
\hline iso- $\mathrm{C}_{16: 0}$ & $0.5 \pm 0.6(1.1)$ & - & - \\
\hline anteiso- $\mathrm{C}_{16: 0}$ & $2.1 \pm 0.1(1.9)$ & 1.5 & 1.2 \\
\hline Summed feature 3 & $4.4 \pm 0.4(4.0)$ & 14.3 & 12.2 \\
\hline $\mathrm{C}_{16: 0}$ & $3.9 \pm 0.9(2.6)$ & 3.3 & 3.2 \\
\hline iso- $\mathrm{C}_{15: 0} 3-\mathrm{OH}$ & $9.1 \pm 0.4(8.8)$ & 4.6 & 2.1 \\
\hline $\mathrm{C}_{15: 0} 2-\mathrm{OH}$ & - & - & 1.0 \\
\hline iso- $\mathrm{C}_{16: 0} 3-\mathrm{OH}$ & $2.6 \pm 0.4(3.2)$ & - & - \\
\hline $\mathrm{C}_{16: 0} 3-\mathrm{OH}$ & $4.5 \pm 1.6(2.1)$ & 2.7 & 3.0 \\
\hline iso- $\mathrm{C}_{17: 0} 3-\mathrm{OH}$ & $13.7 \pm 1.8(15.1)$ & 15.6 & 14.0 \\
\hline
\end{tabular}

Cells are Gram-negative, strictly aerobic, non-gliding, nonfilamentous single rods. Colonies are rusty in colour. Flexirubin-like pigments are not found. Catalase and oxidase are positive. Nitrate is not reduced under either anaerobic or aerobic conditions. Predominant respiratory quinone is MK7. Cellular fatty acids include large amounts of iso- $\mathrm{C}_{15: 0}$ and iso- $\mathrm{C}_{15: 1} \mathrm{G}$. The $\mathrm{G}+\mathrm{C}$ content of chromosomal DNA is $38.5-39.5 \mathrm{~mol} \%$. Phylogenetically positioned within the family 'Chitinophagaceae', class 'Sphingobacteria', phylum Bacteroidetes. The type species is Ferruginibacter alkalilentus.

\section{Description of Ferruginibacter alkalilentus sp. nov.}

Ferruginibacter alkalilentus (al.ka.li.len'tus. N.L. n. alkali from the Arabic word al-qaliy, the ashes of saltwort; L. adj. lentus, $-a$, -um tough, resistant; N.L. masc. adj. alkalilentus resistant to alkaline solution, referring to negative reaction for the flexirubin- $\mathrm{KOH}$ test)

Rod-like cells occur as single units, $0.3-0.5 \mu \mathrm{m}$ in diameter, but vary in length and shape depending on age.

Table 3. Differential characteristics between Ferruginibacter species and Terrimonas ferruginea

Strains: 1, Ferruginibacter alkalilentus (5 strains included); 2, Ferruginibacter lapsinanis $\mathrm{HU} 1-\mathrm{HG}_{4} 2^{\mathrm{T}}$; 3, Terrimonas ferruginea IAM $15098^{\mathrm{T}}$ (Xie \& Yokota, 2006). All strains are positive for hydrolysis of 2-naphthylphosphate $(\mathrm{pH} \mathrm{8.5)}$ and negative for: production of $\mathrm{H}_{2} \mathrm{~S}$ and indole, hydrolysis of DNA, 6-bromo-2naphthyl- $\alpha$-D-galactopyranoside, 2 -naphthyl- $\beta$-D-galactopyranoside, 6-bromo-2-naphthyl- $\beta$-D-glucopyranoside, naphthol-AS-BI- $\beta$-D-glucuronide, 6-bromo-2-naphthyl- $\alpha$-D-mannopyranoside and 2naphthylmyristate, acid production from inositol, mannitol and sucrose, and assimilation of dulcitol, fructose, galactose and glycerol. + , All strains positive; -, all strains negative; w, all strains weakly positive; $\mathrm{v}(+)$, strain-dependent and positive for type strain; $\mathrm{v}(\mathrm{w})$, strain-dependent and weakly positive for type strain; ND, no data available.

\begin{tabular}{|c|c|c|c|}
\hline Characteristic & 1 & 2 & 3 \\
\hline Growth on nutrient agar (Difco) & - & - & + \\
\hline $\begin{array}{l}\text { Highest } \mathrm{NaCl} \text { concentration }(\%, \mathrm{w} / \mathrm{v}) \\
\text { tolerated }\end{array}$ & $<0.5$ & $<0.5$ & 1 \\
\hline \multicolumn{4}{|l|}{ Hydrolysis of: } \\
\hline L-Leucyl-2-naphthylamide & - & + & + \\
\hline$p$-Nitrophenyl- $\beta$-D-galactopyranoside & $\mathrm{W}$ & - & ND \\
\hline \multicolumn{4}{|l|}{ Assimilation of: } \\
\hline L-Arabinose & $\mathrm{v}(\mathrm{w})$ & - & - \\
\hline Citrate & $\mathrm{v}(\mathrm{w})$ & + & - \\
\hline Glucose & $\mathrm{v}(\mathrm{w})$ & - & + \\
\hline Melibiose & $\mathrm{v}(+)$ & - & - \\
\hline Raffinose & + & - & - \\
\hline Rhamnose & - & - & + \\
\hline Trehalose & + & - & - \\
\hline D-Xylose & + & - & + \\
\hline
\end{tabular}


Cells of young cultures (2 days old) are straight, slender, 3-5 $\mu \mathrm{m}$ long, with slightly tapered ends; cells of 5-day-old cultures are curved or sometimes semicircle-shaped (straindependent), $1-3 \mu \mathrm{m}$ long with rounded or tapered (straindependent) ends. Colonies grown on $\mathrm{R} 2 \mathrm{~A}$ at $30{ }^{\circ} \mathrm{C}$ for 5 days are circular and convex with an entire margin, $0.7-1.2 \mathrm{~mm}$ in diameter, translucent, glossy and rusty in colour, and tend to be slimy. Temperature range for growth is $18-30{ }^{\circ} \mathrm{C}$; growth rate is strain-dependent. Cells grow within the $\mathrm{pH}$ range $6-8$ in the presence of less than $0.5 \%$ $(\mathrm{w} / \mathrm{v}) \mathrm{NaCl}$. No growth on either MacConkey agar or nutrient agar (Difco). $\mathrm{H}_{2} \mathrm{~S}$ production, indole production, nitrite reduction and acetoin production from pyruvate are not observed. Aesculin, gelatin, skim milk and urea are hydrolysed, but hydroxyethylcellulose, DNA, starch and xylan are not. No acid is produced from amygdalin, Larabinose, D-mannitol, D-melibiose, L-rhamnose or Dsucrose. Activity for arginine dihydrolase is present, but activities for lysine decarboxylase, ornithine decarboxylase and tryptophan deaminase are not. 2-Naphthylphosphate (pH 8.5), naphthol-AS-BI-phosphate (weakly) and p-nitrophenyl- $\beta$-D-galactopyranoside (weakly) are hydrolysed, but $N$-benzoyl-DL-arginine 2-naphthylamide, 2-naphthylbutyrate, L-cystyl-2-naphthylamide, $\mathrm{N}$-glutarylphenylalanine 2naphthylamide, 2-naphthyl- $\alpha$-L-fucopyranoside, $o$-nitrophenyl- $\beta$-D-galactopyranoside, 2 -naphthyl- $\alpha$-D-glucopyranoside and L-valyl-2-naphthylamide are not. Hydrolysis of L-naphthyl- $N$-acetyl- $\beta$-D-glucosaminide is strain-dependent (negative for type strain). All strains can utilize D-raffinose, D-trehalose, xylitol (weakly) and D-xylose as sole carbon sources, but the following compounds are not assimilated: adipate, adonitol, L-alanine, amygdalin, benzoate, caprate, D-cellobiose, dextran, formate, D-fructose, L-fucose, fumarate, D-galactose, glutarate, glycogen, L-histidine, 3-hydroxybenzoate, 4-hydroxybenzoate, 3-hydroxybutyrate, inulin, itaconate, 2-ketogluconate, 5-ketogluconate, DL-lactate, Dlactose, D-lyxose, malate, maleate, malonate, D-maltose, oxalate, phenylacetate, L-proline, propionate, pyruvate, Dribose, L-rhamnose, salicin, L-serine, L-sorbose, suberate, succinate, tartrate, tyrosine, valerate and L-xylose. Utilization of $\mathrm{N}$-acetyl-D-glucosamine, D-melibiose and Dsucrose (positive for type strain), acetate, L-arabinose, citrate, gluconate, D-glucose, inositol, D-mannitol, D-mannose and D-sorbitol (weakly positive for type strain) and Darabinose (negative for type strain) are strain-dependent. Additional characteristics are listed in Tables $1-3$ and the genus description, or described elsewhere in the text.

The type strain, HU1-GD $23^{\mathrm{T}}\left(=\mathrm{KCTC} 22306^{\mathrm{T}}=\mathrm{LMG}\right.$ $\left.24312^{\mathrm{T}}\right)$, and four other strains, HU1-GB11 (=KCTC $22307=$ LMG 24310), HU1-ID41 $(=$ KCTC $22308=$ LMG 24325), HU1-IH3 (=KCTC 22304=LMG 24326) and HU1-JE21 (=KCTC 22303=LMG 24327), were isolated from freshwater sediment.

\section{Description of Ferruginibacter lapsinanis sp. nov.}

Ferruginibacter lapsinanis (lap.si'na.nis. L. n. lapsus -us gliding; L. adj. inanis void; N.L. masc. adj. void of gliding motility)
Cells grown on R2A at $30{ }^{\circ} \mathrm{C}$ for 5 days are single, short rods, $1-2 \mu \mathrm{m}$ long and $0.3-0.5 \mu \mathrm{m}$ wide. Colonies are circular and convex with an entire margin, slimy, translucent, glossy, rusty in colour, and reach $1-2.2 \mathrm{~mm}$ in diameter after 5 days incubation. Growth occurs at $18-30{ }^{\circ} \mathrm{C}$ and at $\mathrm{pH} 6-8$ with less than $0.5 \%(\mathrm{w} / \mathrm{v}) \mathrm{NaCl}$. No growth on either MacConkey agar or nutrient agar (Difco). $\mathrm{H}_{2} \mathrm{~S}$ production, indole production, nitrite reduction and acetoin production from pyruvate are not observed. Aesculin, gelatin, skim milk and urea are hydrolysed, but hydroxyethylcellulose, DNA, starch and xylan are not. Acid is not produced from amygdalin, Larabinose, D-mannitol, D-melibiose, L-rhamnose or Dsucrose. Activity for arginine dihydrolase is present, but activities for lysine decarboxylase, ornithine decarboxylase and tryptophan deaminase are not. L-Leucyl-2-naphthylamide, 2-naphthylphosphate ( $\mathrm{pH} 8.5)$ and naphthol-AS$\mathrm{BI}$-phosphate (weakly) are hydrolysed, but $N$-benzoyl-DLarginine 2-naphthylamide, 2-naphthylbutyrate, L-cystyl-2naphthylamide, $N$-glutarylphenylalanine 2-naphthylamide, 2 -naphthyl- $\alpha$-L-fucopyranoside, 2-naphthyl- $\alpha$-D-glucopyranoside, $o$-nitrophenyl- $\beta$-D-galactopyranoside, L-naphthyl$N$-acetyl- $\beta$-D-glucosaminide and L-valyl-2-naphthylamide are not. Only citrate among the substrates tested is utilized as sole carbon source and the following compounds are not: acetate, adipate, adonitol, L-alanine, amygdalin, Darabinose, benzoate, caprate, D-cellobiose, dextran, formate, D-fructose, L-fucose, fumarate, D-galactose, gluconate, $\mathrm{N}$-acetyl-D-glucosamine, D-glucose, glutarate, glycogen, Lhistidine, 3-hydroxybenzoate, 4-hydroxybenzoate, 3hydroxybutyrate, inositol, inulin, itaconate, 2-ketogluconate, 5-ketogluconate, DL-lactate, D-lactose, D-lyxose, malate, maleate, malonate, D-maltose, D-mannitol, Dmannose, D-melibiose, oxalate, phenylacetate, L-proline, propionate, pyruvate, D-raffinose, D-ribose, L-rhamnose, salicin, L-serine, D-sorbitol, L-sorbose, suberate, succinate, D-sucrose, tartrate, D-trehalose, tyrosine, valerate, xylitol and L-xylose. Additional characteristics are listed in Tables 1-3 and the genus description, or described elsewhere in the text.

The type strain, HU1-HG42 ${ }^{\mathrm{T}}\left(=\mathrm{KCTC} 22305^{\mathrm{T}}=\mathrm{LMG}\right.$ $\left.24324^{\mathrm{T}}\right)$, was isolated from freshwater sediment.

\section{Acknowledgements}

This work was supported by the 21C Frontier Microbial Genomics and Application Center Program, Ministry of Science \& Technology (Grant MG08-0101-2-0), Republic of Korea.

\section{References}

An, D. S., Lee, H. G., Im, W. T., Liu, Q. M. \& Lee, S. T. (2007). Segetibacter koreensis gen. nov., sp. nov., a novel member of the phylum Bacteroidetes, isolated from the soil of a ginseng field in South Korea. Int J Syst Evol Microbiol 57, 1828-1833.

Atlas, R. M. (2004). Handbook of Microbiological Media, 3rd edn. Boca Raton: CRC Press. 
Buck, J. D. (1982). Nonstaining (KOH) method for determination of Gram reactions of marine bacteria. Appl Environ Microbiol 44, 992-993.

Button, D. K., Schut, F., Quang, P., Martin, R. \& Robertson, B. R. (1993). Viability and isolation of marine bacteria by dilution culture: theory, procedures, and initial results. Appl Environ Microbiol 59, 881-891.

Cowan, S. T. \& Steel, K. J. (1965). Manual for the Identification of Medical Bacteria. London: Cambridge University Press.

Fautz, E. \& Reichenbach, H. (1980). A simple test for flexirubin-type pigments. FEMS Microbiol Lett 8, 87-91.

Felsenstein, J. (1985). Confidence limits on phylogenies: an approach using the bootstrap. Evolution 39, 783-791.

Fitch, W. M. (1971). Toward defining the course of evolution: minimum change for a specific tree topology. Syst Zool 20, 406-416.

Fujita, T., Okamoto, M., Kosako, Y. \& Okuhara, M. (1996). Flexibacter japonensis sp. nov., a new species that produces a novel inhibitor of human leukocyte elastase isolated from soil. Curr Microbiol 33, 89-93.

Garrity, G. M. \& Holt, J. G. (2001). The road map to the Manual. In Bergey's Manual of Systematic Bacteriology, 2nd edn, vol. 1, pp. 119166. Edited by D. R. Boone, R. W. Castenholz \& G. M. Garrity. New York: Springer.

Hall, T. A. (1999). BioEdit: a user-friendly biological sequence alignment editor and analysis program for Windows 95/98/NT. Nucleic Acids Symp Ser 41, 95-98.

Kämpfer, P., Young, C. C., Sridhar, K. R., Arun, A. B., Lai, W. A., Shen, F. T. \& Rekha, P. D. (2006). Transfer of [Flexibacter] sancti, [Flexibacter] filiformis, [Flexibacter] japonensis and [Cytophaga] arvensicola to the genus Chitinophaga and description of Chitinophaga skermanii sp. nov. Int J Syst Evol Microbiol 56, 2223-2228.

Kim, B. Y., Weon, H. Y., Yoo, S. H., Hong, S. B., Kwon, S. W., Stackebrandt, E. \& Go, S. J. (2007). Niabella aurantiaca gen. nov., sp. nov., isolated from a greenhouse soil in Korea. Int J Syst Evol Microbiol 57, 538-541.

Kimura, M. (1983). The Neutral Theory of Molecular Evolution. Cambridge, UK: Cambridge University Press.

Komagata, K. \& Suzuki, K. (1987). Lipid and cell-wall analysis in bacterial systematics. Methods Microbiol 19, 161-207.

Kumar, S., Tamura, K. \& Nei, M. (2004). MEGA3: integrated software for Molecular Evolutionary Genetics Analysis and sequence alignment. Brief Bioinform 5, 150-163.

Lane, D. J. (1991). 16S/23S rRNA sequencing. In Nucleic Acid Techniques in Bacterial Systematics, pp. 115-175. Edited by E. Stackebrandt \& M. Goodfellow. Chichester: Wiley.

Lane, D. J., Pace, B., Olsen, G. J., Stahl, D. A., Sogin, M. L. \& Pace, N. R. (1985). Rapid determination of $16 \mathrm{~S}$ ribosomal RNA sequences for phylogenetic analyses. Proc Natl Acad Sci U S A 82, 6955-6959.

Lim, J. H., Baek, S. H. \& Lee, S. T. (2008). Burkholderia sediminicola sp. nov., isolated from freshwater sediment. Int J Syst Evol Microbiol 58, 565-569.

Ludwig, W., Euzéby, J. \& Whitman, W. B. (2008). Draft taxonomic outline of the Bacteroidetes, Planctomycetes, Chlamydiae, Spirochaetes, Fibrobacteres, Fusobacteria, Acidobacteria, Verrucomicrobia, Dictyoglomi, and Gemmatimonadetes. http://www.bergeys.org/outlines/ Bergeys_Vol_4_Outline.pdf

Mesbah, M., Premachandran, U. \& Whitman, W. B. (1989). Precise measurement of the $\mathrm{G}+\mathrm{C}$ content of deoxyribonucleic acid by highperformance liquid chromatography. Int J Syst Bacteriol 39, 159-167.

Muyzer, G., de Waal, E. C. \& Uitterlinden, A. G. (1993). Profiling of complex microbial populations by denaturing gradient gel electrophoresis analysis of polymerase chain reaction-amplified genes coding for 16S rRNA. Appl Environ Microbiol 59, 695-700.
Pedersen, K. \& Ekendahl, S. (1990). Distribution and activity of bacteria in deep granitic groundwaters of southeastern Sweden. Microb Ecol 20, 37-52.

Qu, J. H. \& Yuan, H. L. (2008). Sediminibacterium salmoneum gen. nov., sp. nov., a member of the phylum Bacteroidetes isolated from sediment of a eutrophic reservoir. Int J Syst Evol Microbiol 58, 21912194.

Reichenbach, H. (1989a). Genus Flexibacter Soriano 1945, $92^{\mathrm{AL}}$ emend. In Bergey's Manual of Systematic Bacteriology, 1st edn, vol. 3, pp. 2061-2071. Edited by J. T. Staley, M. P. Bryant, N. Pfennig \& J. G. Holt. Baltimore: Williams \& Wilkins.

Reichenbach, H. (1989b). Genus I. Cytophaga Winogradsky 1929, $577^{\mathrm{AL}}$ emend. In Bergey's Manual of Systematic Bacteriology, 1st edn, vol. 3, pp. 2015-2050. Edited by J. T. Staley, M. P. Bryant, N. Pfennig \& J. G. Holt. Baltimore: Williams \& Wilkins.

Saitou, N. \& Nei, M. (1987). The neighbor-joining method: a new method for reconstructing phylogenetic trees. Mol Biol Evol 4, 406425.

Sangkhobol, V. \& Skerman, V. B. D. (1981). Chitinophaga, a new genus of chitinolytic Myxobacteria. Int J Syst Bacteriol 31, 285-293.

Skerman, V. B. D. (1989). Genus Chitinophaga Sangkhobol and Skerman 1981, 285 VP. In Bergey's Manual of Systematic Bacteriology, 1st edn, vol. 3, pp. 2074-2077. Edited by J. T. Staley, M. P. Bryant, N. Pfennig \& J. G. Holt. Baltimore: Williams \& Wilkins.

Stoecker, K., Bendinger, B., Schöning, B., Nielsen, P. H., Nielsen, J. L., Baranyi, C., Toenshoff, E. R., Daims, H. \& Wagner, M. (2006). Cohn's Crenothrix is a filamentous methane oxidizer with an unusual methane monooxygenase. Proc Natl Acad Sci U S A 103, 2363-2367.

Swindell, S. R. \& Plasterer, T. N. (1997). SEQMAN: contig assembly. Methods Mol Biol 70, 75-89.

Ten, L. N., Im, W. T., Kim, M. K., Kang, M. S. \& Lee, S. T. (2004). Development of a plate technique for screening of polysaccharidedegrading microorganisms by using a mixture of insoluble chromogenic substrates. J Microbiol Methods 56, 375-382.

Thompson, J. D., Gibson, T. J., Plewniak, F., Jeanmougin, F. \& Higgins, D. G. (1997). The CLUSTAL_X windows interface: flexible strategies for multiple sequence alignment aided by quality analysis tools. Nucleic Acids Res 25, 4876-4882.

Tschech, A. \& Pfennig, N. (1984). Growth yield increase linked to caffeate reduction in Acetobacterium woodii. Arch Microbiol 137, 163167.

Weon, H. Y., Kim, B. Y., Yoo, S. H., Lee, S. Y., Kwon, S. W., Go, S. J. \& Stackebrandt, E. (2006). Niastella koreensis gen. nov., sp. nov. and Niastella yeongjuensis sp. nov., novel members of the phylum Bacteroidetes, isolated from soil cultivated with Korean ginseng. Int J Syst Evol Microbiol 56, 1777-1782.

Weon, H. Y., Kim, B. Y., Joa, J. H., Kwon, S. W., Kim, W. G. \& Koo, B. S. (2008). Niabella soli sp. nov., isolated from soil from Jeju Island, Korea. Int J Syst Evol Microbiol 58, 467-469.

Widdel, F. \& Bak, F. (1992). Gram-negative mesophilic sulfate reducing bacteria. In The Prokaryotes, 2nd edn, vol. 4, pp. 3352-3378. Edited by A. Balows, H. G. Trüper, M. Dworkin, W. Harder \& K.-H. Schleifer. New York: Springer

Xie, C. H. \& Yokota, A. (2006). Reclassification of [Flavobacterium] ferrugineum as Terrimonas ferruginea gen. nov., comb. nov., and description of Terrimonas lutea sp. nov., isolated from soil. Int J Syst Evol Microbiol 56, 1117-1121.

Yoon, M. H. \& Im, W. T. (2007). Flavisolibacter ginsengiterrae gen. nov., sp. nov., and Flavisolibacter ginsengisoli sp. nov., isolated from ginseng cultivating soil. Int J Syst Evol Microbiol 57, 1834-1839. 